\title{
PROPERTIES OF A FISSIUM-TYPE ALLOY
}

$\because$

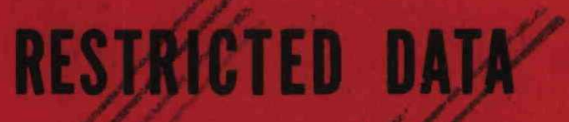

This document contains restrjeted lata as defined in the Atomic Enersilat of 1954.

Its transmittal or the disofosure of it: contents in any manney to an unauthorized person is profibitited.

This document contains Confidential-Restricted Data relating to civilian applications of atomic energy.

AEC RESEARCH AND DEYELOPMENT REPORT

\section{BATTELLE MEMORIAL INSTITUTE}

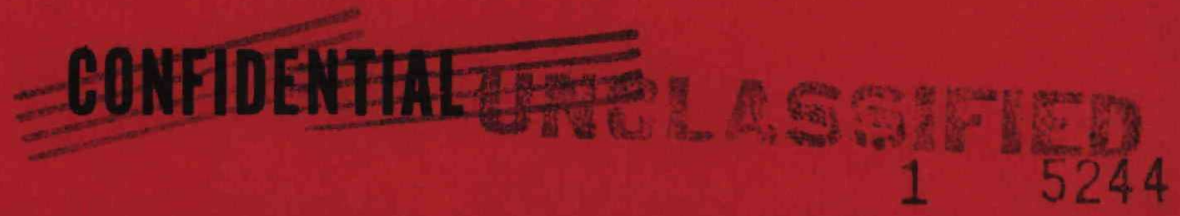




\section{LEGAL NOTICE}

This report was prepared as an account of Government iponsored work. Net ther the Unired States, nor the Commission, nor any person aeting on behalf of the Commissiont

A. Makes ony warranty or representation, express or implied, with respect to the ocsuracy, completeness, or usefulness of the information contained in this report, or that the use of any information, apparatus, method, or process disclosed in this report may not inuse of any information, apporatus,

B. Assumes any liabilities with respect to the use of, or for damages resulting from the use of any information, oppuratus, method, or process disclosed in this report.

As used in the above, "person acting on behalf of the Commission" includes any employee or contractor of the Commission to the extent that such employee or contrector prepares, handles or distribures, or provides access to, any information pursuant to his employment or contract with the Commission.

\section{Printed in USA}

\section{Charge 35 cents}

Available from the

U. S. Atomic Energy Commission

Technical Information Extension

P. O. Box 1001 , Oak Ridge, Tennessee

Please direct to the same address in quiries covering the procurement of other classified AEC reports. 


\section{DISCLAIMER}

This report was prepared as an account of work sponsored by an agency of the United States Government. Neither the United States Government nor any agency Thereof, nor any of their employees, makes any warranty, express or implied, or assumes any legal liability or responsibility for the accuracy, completeness, or usefulness of any information, apparatus, product, or process disclosed, or represents that its use would not infringe privately owned rights. Reference herein to any specific commercial product, process, or service by trade name, trademark, manufacturer, or otherwise does not necessarily constitute or imply its endorsement, recommendation, or favoring by the United States Government or any agency thereof. The views and opinions of authors expressed herein do not necessarily state or reflect those of the United States Government or any agency thereof. 


\section{DISCLAIMER}

Portions of this document may be illegible in electronic image products. Images are produced from the best available original document. 


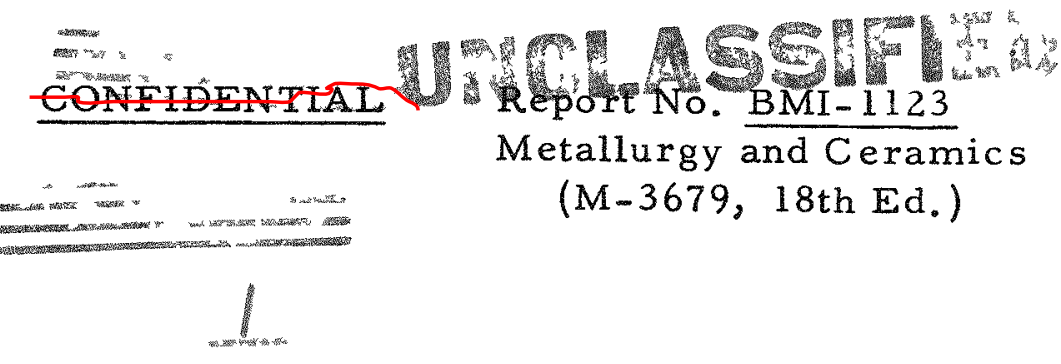

Contract No. W-7405-eng-92

PROPERTIES OF A FISSIUM-TYPE ALLOY

by

Henry A. Saller

Ronald F. Dickerson

Arthur A. Bauer

Norman E. Daniel

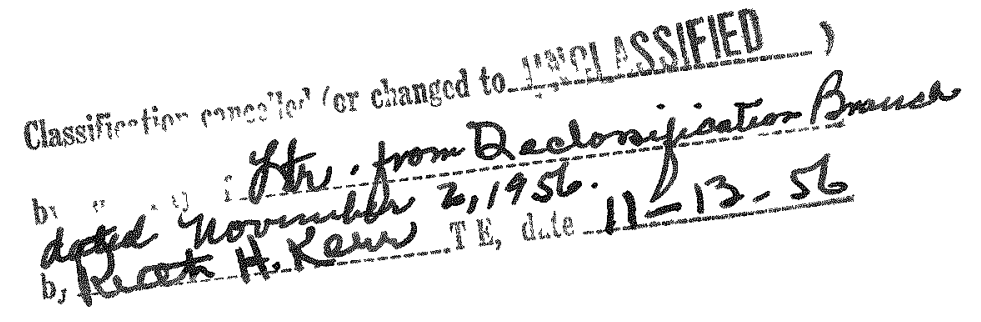

August 3, 1956

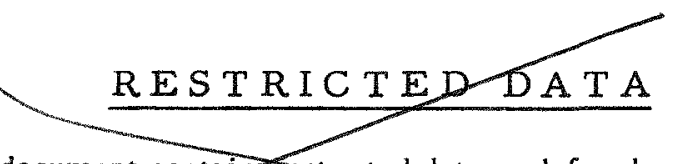

This document contains festucted data as defined in the Atomic Energy Act of 1954. Its transmittator disclosure of its contents in any manner to an unauthorized person is prohibited.

BATTELLE MEMORIAL INSTITUTE $505 \mathrm{King}$ Avenue Columbus 1 , Ohio

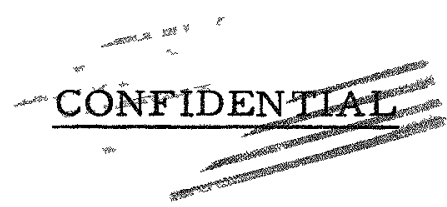


2

-

-

. 
ABSTRACT . . . . . . . . . . . . . . . . . 5

INT RODUCTION . . . . . . . . . . . . . . . . . . 5

ALLOY PREPARATION . . . . . . . . . . . . . . . 6

HEAT-TREATMENT STUDIES . . . . . . . . . . . . 6

Experimental Procedures . . . . . . . . . . . . 7

Results and Discussion . . . . . . . . . . . . . 7

PHYSICAL PROPERTIES . . . . . . . . . . . . . . 20

Melting Point . . . . . . . . . . . . . . . 20

Fluidity . . . . . . . . . . . . . . . . . . 21

Thermal Conductivity . . . . . . . . . . . . . . 21

Linear Thermal Expansion . . . . . . . . . . . 24

Density . . . . . . . . . . . . . . . . . 27

Thermal Stability. . . . . . . . . . . . . . 27

Hot Hardness . . . . . . . . . . . . . . . . 27

Tensile Properties . . . . . . . . . . . . . . 32

CONCLUSIONS . . . . . . . . . . . . . . . . . 32 
-

- 


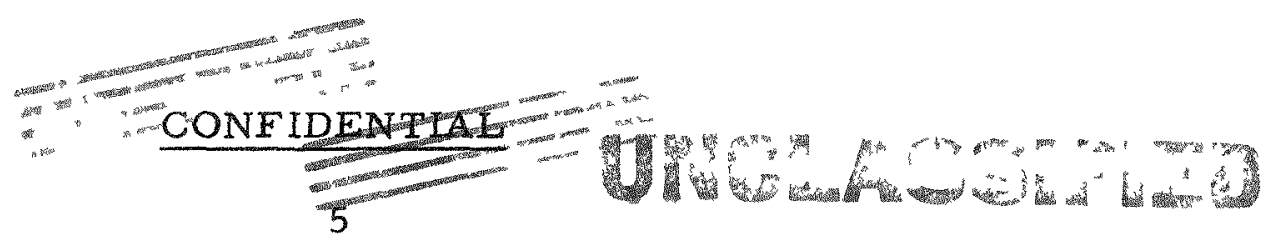

PROPERTIES OF A FISSIUM-TYPE ALLOY

\author{
Henry A. Saller, Ronald F. Dickerson, Arthur A. Bauer, \\ and Normal E. Daniel
}

\begin{abstract}
The interest in recycled fuels for use in power reactors has led to a study of a fissium-type alloy, which may be defined as an artificial alloy representing fuel containing an equilibrium amount of fission products produced after an infinite number of irradiation and metallurgical reprocessing cycles. The nominal composition of the alloy was as follows: $2.5 \mathrm{w} / \mathrm{o}$ molybdenum, $1.5 \mathrm{w} / \mathrm{o}$ ruthenium, $0.5 \mathrm{w} / \mathrm{o}$ palladium, $0.3 \mathrm{w} / \mathrm{o}$ rhodium, $0.1 \mathrm{w} / \mathrm{o}$ zirconium, and the balance normal uranium. It was found that the alloy behaved similarly to the binary uranium -5.0 w/o molybdenum alloy during heat treatment and fabrication. The alloy ages relatively fast in the temperature range between 450 and $600 \mathrm{C}$, but it is relatively soft when quenched from $800 \mathrm{C}$ or above.

Indications are that the alloy is less stable during thermal cycling than binary uranium-molybdenum alloys, and that the tensile properties of the alloy will compare favorably with the uranium $5 w / o$ molybdenum alloy. However, before any conclusions can be drawn in regard to the possible use of such an alloy in reactor fuel elements, a more exhaustive study of the alloy should be made.
\end{abstract}

\title{
INTRODUCTION
}

An increased interest in the use of recycled oxide-slagged fuels for use in power reactors has instigated an investigation of the properties of such an alloy. The reference alloy for this program represents a compromise between the high-plutonium fuels such as used in the PBR and the high-uranium fuels used in other reactors. In this report, the alloy referred to as fissium or a fissium-type alloy may be defined as an artificial alloy representing an alloy containing an equilibrium amount of fission products produced as a result of an infinite number of irradiation and pyrometallurgical reprocessing cycles.

Since reactors operate at elevated temperatures, the properties of the alloy at such temperatures should be known as well as the effects of heat treatment on these alloys.

A research program to determine these properties has been conducted at Battelle and the results of this study are presented in this report. It should, however, be emphasized that, as this investigation was designed to be of a general type, an effort has been made to cover many phases briefly
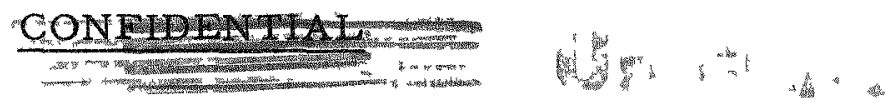
and no attempt was made to embark on an exhaustive study of any particular phase.

\section{ALLOY PREPARATION}

Since the program was limited in scope, it was decided to concentrate the effort upon one synthetically prepared fissium-type alloy. The composition of this alloy is given in Table 1.

TABLE 1. NOMINAL AND ANALYZED COMPOSITION OF THE SYNTHETIC FISSIUM ALLOY

\begin{tabular}{|c|c|c|c|c|}
\hline \multirow[b]{2}{*}{ Element } & \multirow{2}{*}{$\begin{array}{c}\text { Nominal } \\
\text { Composition, } \\
\text { w/o }\end{array}$} & \multicolumn{3}{|c|}{ Chemical Analysis, w/o } \\
\hline & & Melt 1 & Melt 2 & Melt 3 \\
\hline Uranium & 95.1 & 95.12 & 95.11 & 94.95 \\
\hline Molybdenum & 2.5 & 2.33 & 2.48 & 2.56 \\
\hline Zirconium & 0.1 & 0.10 & 0.11 & 0.10 \\
\hline Ruthenium & 1.5 & 1.61 & 1.45 & 1.55 \\
\hline Rhodium & 0.3 & 0.27 & 0.28 & 0.30 \\
\hline Palladium & 0.5 & 0.57 & 0.57 & 0.54 \\
\hline
\end{tabular}

The material was prepared in the form of three $6-\mathrm{kg}$ ingots by induction melting in $\mathrm{ZrO}_{2}$ crucibles and casting into 2-in.-diameter graphite molds. Extensive porosity and piping present in the castings necessitated the cropping of approximately $1 / 3$ of the top from each ingot prior to fabrication. The chemical analyses of the ingots after cropping also appear in Table 1 .

Initial attempts to forge the material at $1200 \mathrm{~F}(650 \mathrm{C})$ were unsuccessful so the forging temperature was increased to $1600 \mathrm{~F}(870 \mathrm{C})$. The alloy forged readily at this temperature. The material was then rolled from a helium-atmosphere furnace at $1250 \mathrm{~F}(675 \mathrm{C})$ to obtain material from which the test specimens were machined to the desired size.

\section{HEAT-TREATMENT STUDIES}

During casting and fabrication studies of the fissium alloy, wide variations in hardness were observed among different ingots and fabricated 
sections. These variations suggested different degrees of transformation and a marked dependence of the degree of transformation on the cooling rate. A brief study was therefore undertaken to determine the heat-treating and transformation characteristics of the alloy.

\section{Experimental Procedures}

In order to determine the isothermal-transformation characteristics of the alloy, fabricated-rod specimens, $1 / 4 \mathrm{in.}$ long by $1 / 4 \mathrm{in}$. in diameter, were annealed in a lead bath for $1 \mathrm{hr}$ at $825 \mathrm{C}$ and isothermally transformed for various periods of time in lead or Wood's metal baths at temperatures ranging from 200 to $625 \mathrm{C}$. Vickers hardness measurements were then made on all specimens.

Selected specimens were prepared for metallographic examination by polishing on Forstmann's cloth, using diamond abrasive. A number of etchants were investigated, but the most satisfactory results were obtained with an electrolytic etchant consisting of phosphoric acid, ethanol, and ethylene glycol in the ratio of $5: 4: 4$.

A few of the metallographic samples were examined by $\mathrm{X}$-ray diffraction techniques. These samples were examined on the metallographically prepared surfaces in a General Electric spectrometer. Etched slivers cut from these samples were also examined in a Debye camera.

An end-quench test was run on a 5/8-in.-diameter bar about $2-1 / 2$ in. long. The bar was sealed in an evacuated Vycor tube and was annealed $1 \mathrm{hr}$ at $825 \mathrm{C}$. The Vycor tube was broken and one end was quenched in a stream of water, the other end being permitted to cool in air. Flat faces, approximately $1 / 4$ in. wide, were machined on opposite faces of the bar for hardness measurements.

In addition, the effect of a number of furnace-cooling treatments on hardness was determined. Specimens were heat treated in a vacuum furnace under a pressure of $10^{-4} \mathrm{~mm}$ of mercury.

Results and Discussion

Hardness curves based on data obtained on specimens isothermally transformed at $200,300,400,450,500,550$, and $600 \mathrm{C}$ are shown in Figures 1 through 6 . No change in hardness was observed after 5000 sec in specimens heat treated at $625 \mathrm{C}$. 


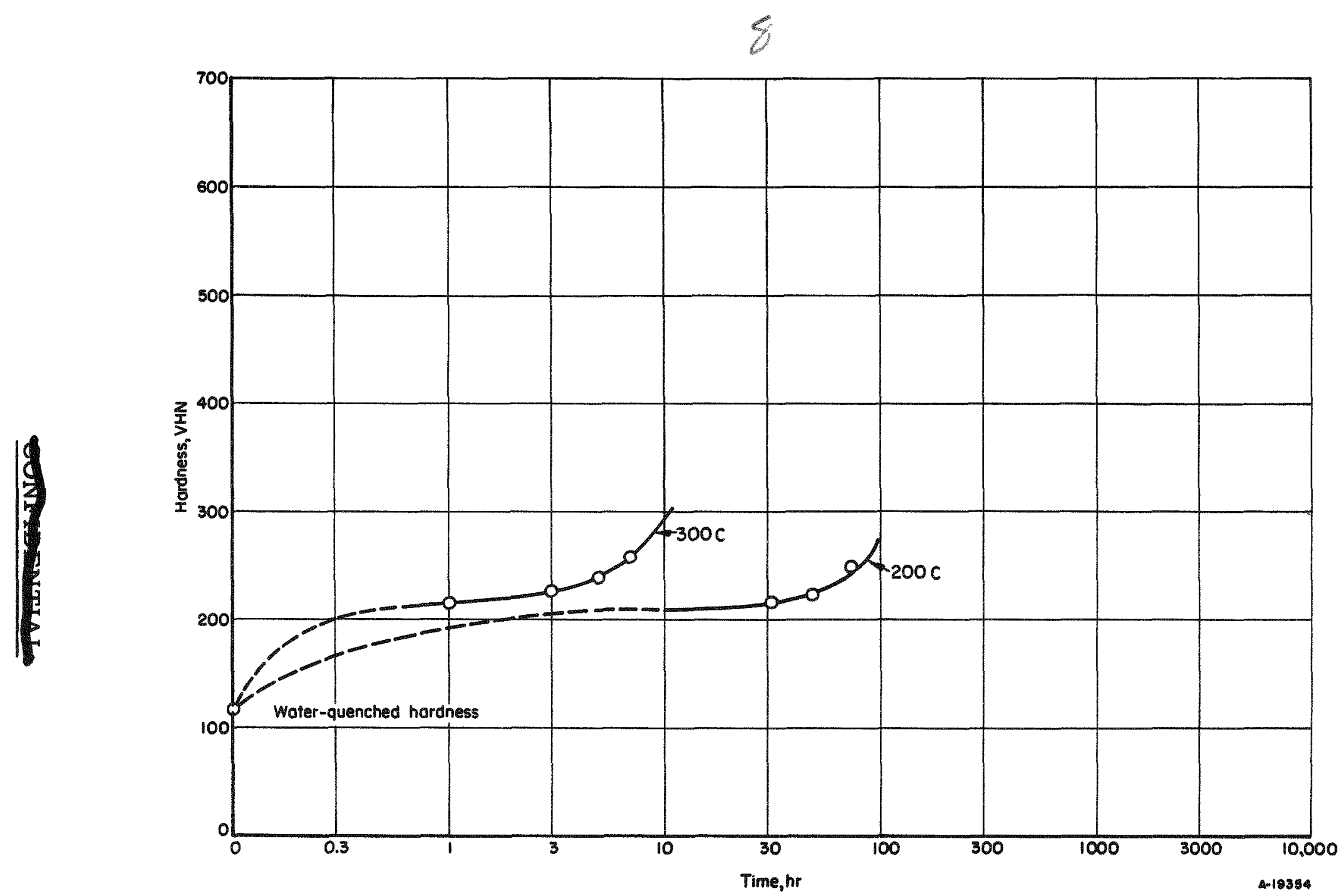

FIGURE 1. HARDNESS CHANGES IN THE FISSIUM ALLOY DURING ISOTHERMAL TRANSFORMATION AT 200 AND $300 \mathrm{C}$ 
9

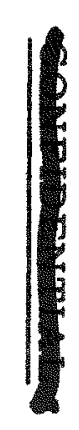

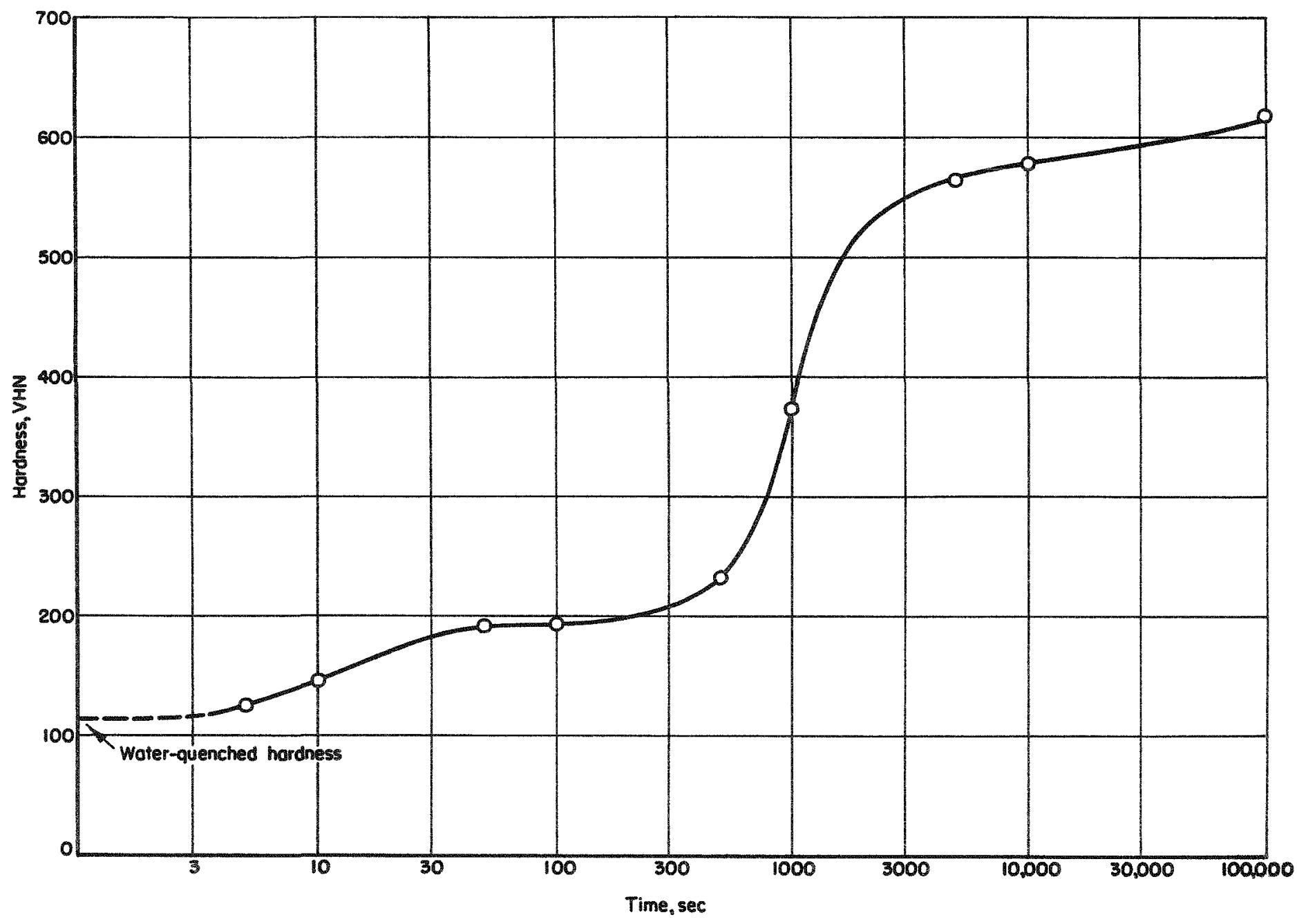

FIGURE 2. HARDNESS CHANGES IN THE FISSIUM ALLOY DURING ISOTHERMAL TRANSFORMATION AT $400 \mathrm{C}$ 


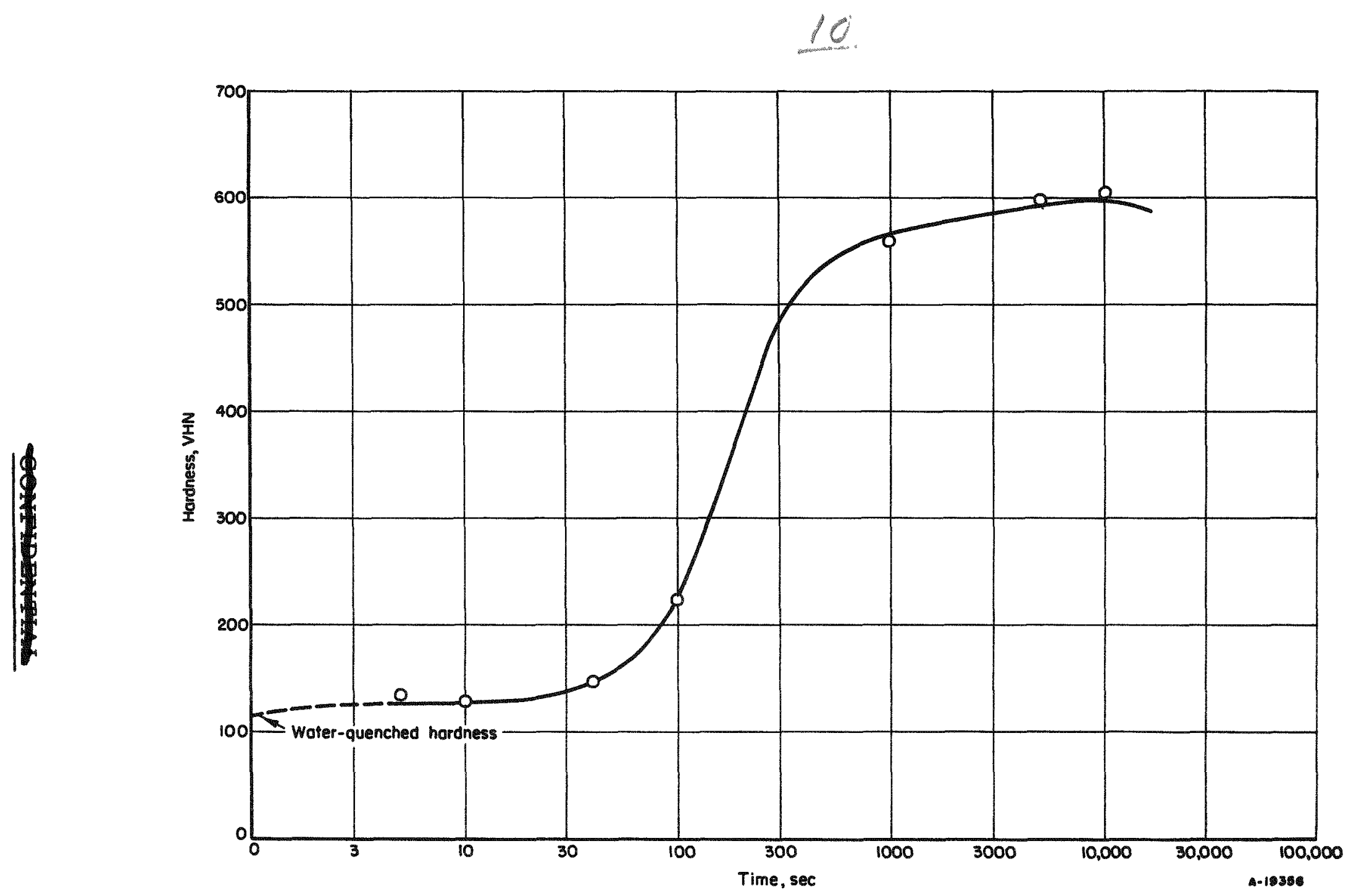

FIGURE 3. HARDNESS CHANGES IN THE FISSIUM ALLOY DURING ISOTHERMAL TRANSFORMATION AT $450 \mathrm{C}$ 


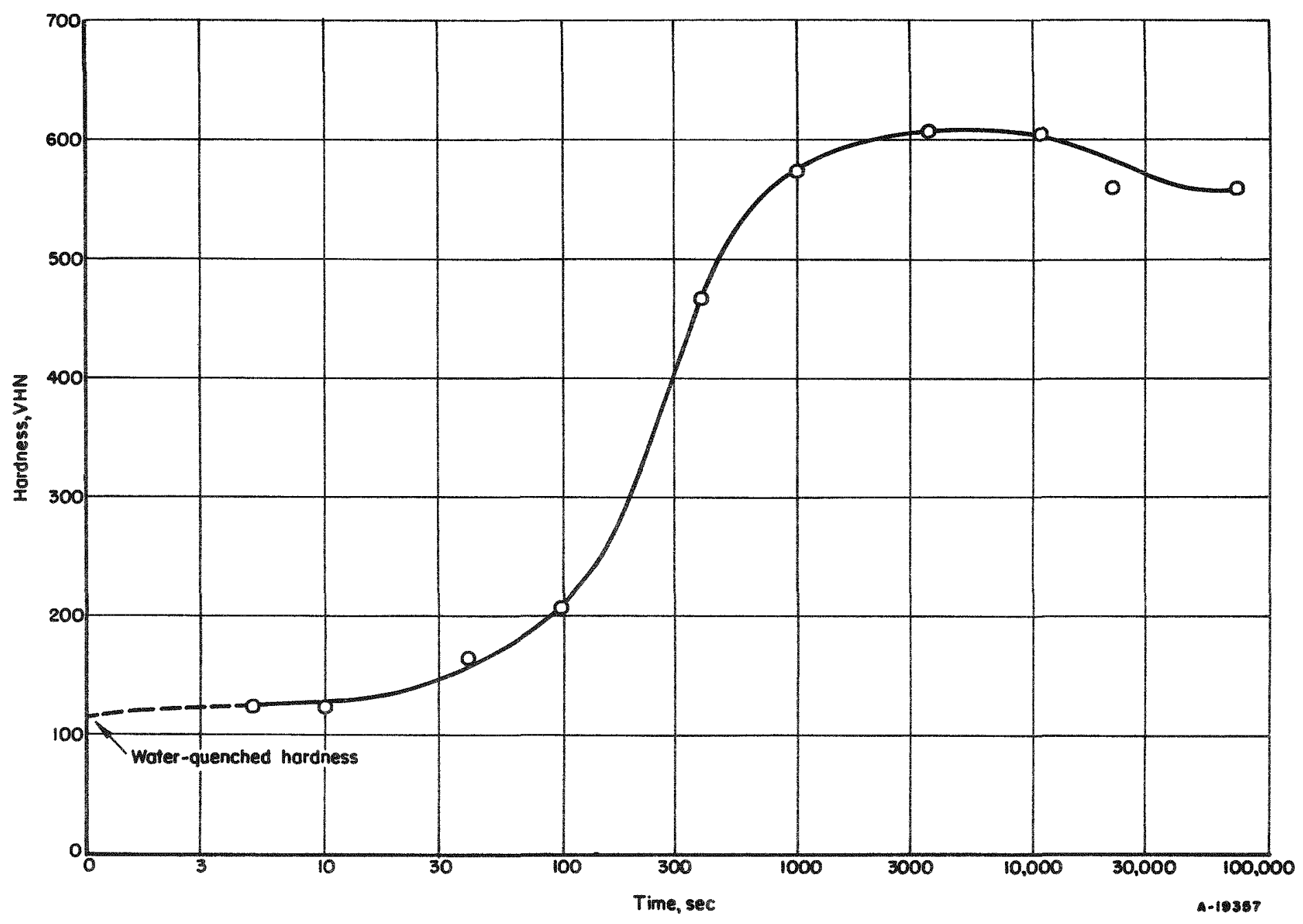

FIG URE 4. HARDNESS CHANGES IN THE FISSIUM ALLOY DURING ISOTHERMAL TRANSFORMATION AT $500 \mathrm{C}$ 


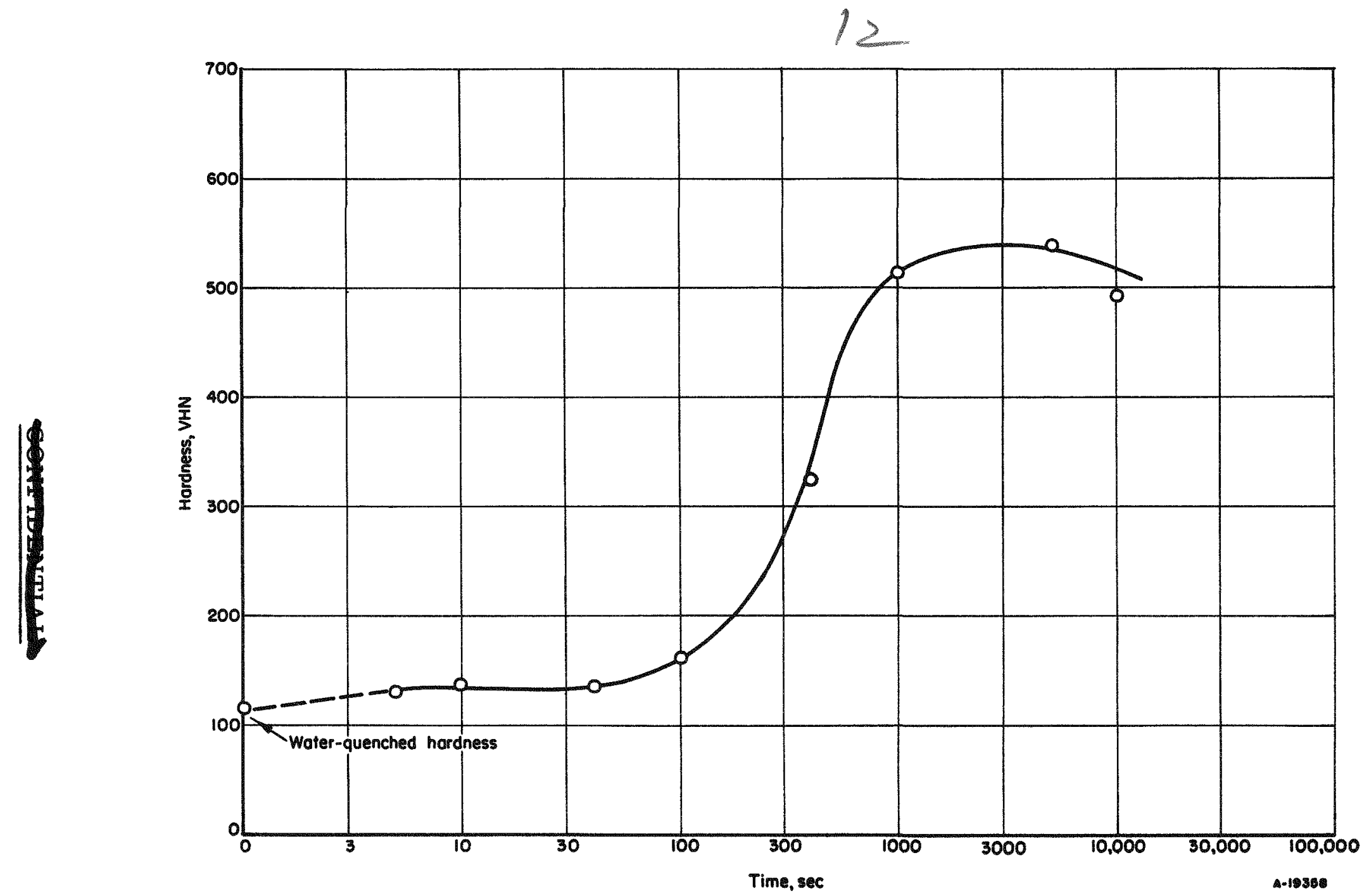

FIGURE 5. HARDNESS CHANGES IN THE FISSIUM ALLOY DURING ISOT HERMAL TRANSFORMATION AT $550 \mathrm{C}$ 
13

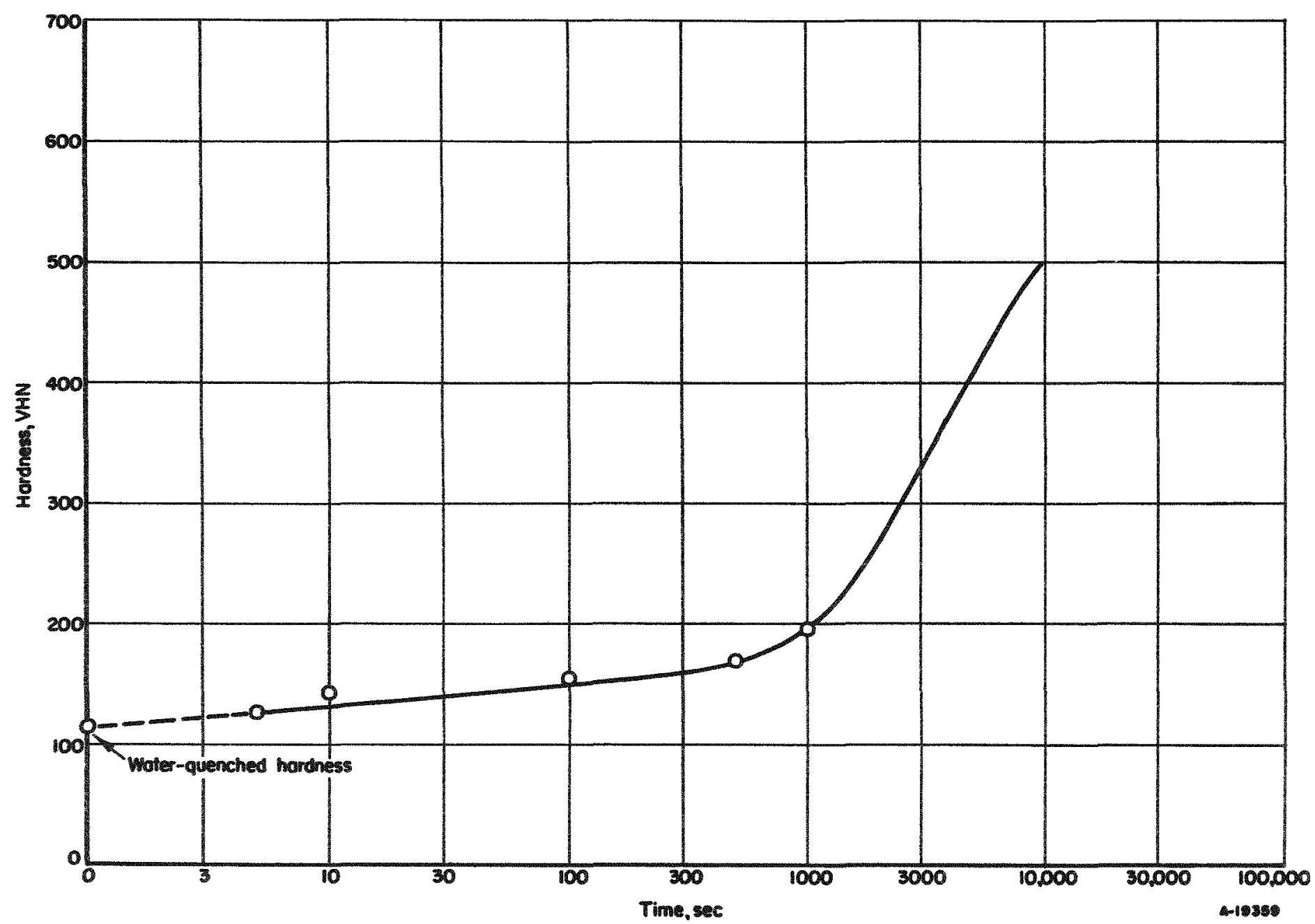

FIGURE 6. HARDNESS CHANGES IN THE FISSIUM ALLOY DURING ISOTHERMAL TRANSFORMATION AT $600 \mathrm{C}$ 
At temperatures between 400 and $550 \mathrm{C}$, where fairly complete hardness curves were obtained, a marked change in hardness is observed with time. While the water-quenched specimen has a hardness of $115 \mathrm{VHN}$, aged specimens achieve hardnesses of over 600 VHN. X-ray diffraction results show that the structures at these respective stages are that of retained gamma in the soft condition and of alpha uranium in the very hard condition with unidentifiable traces of other phases. At intermediate stages gamma and alpha uranium are identified together.

$X$-ray diffraction examination of the transformed specimens revealed some evidence of strain in the alpha phase, as indicated by a broadening of back-reflection lines. However, it appears improbable that the marked hardness changes can be attributed to the formation of alpha uranium alone. Metallographic examination indicates that precipitation aging of supersaturated alpha is the more probable cause of the hardening observed.

Figures 7 through 11 illustrate typical microstructural changes which accompany transformation.

Retained gamma, illustrated in Figure 7, shows little evidence of a second phase, indicating essentially complete solution of the alloy constituents at $825 \mathrm{C}$. Fine twin bands observed within the grains are probably the result of stresses introduced on quenching.

On aging at $500 \mathrm{C}$, precipitation is first observed at the gamma grain boundaries, as evidenced by a thickening of these boundaries shown in Figure 8. With increased aging times, illustrated by Figures 9 and 10, precipitation within the grains becomes evident by a gradual darkening of the matrix. This precipitation of very fine particles that are unresolvable at low magnifications is accompanied by increased grain-boundary precipitate. Figure 11 shows a structure in which coalescence of these particles and consequent overaging has begun.

The time-temperature relationships for the hardness changes accompanying the retained-gamma decomposition have been estimated from the hardness curves and a plot of these relationships is constructed in Figure 12. Apparently, if hardness changes and transformation are directly related, the maximum transformation rate in the alloy occurs at about $475 \mathrm{C}$.

In addition to the aging mechanism just described, a low-temperature pretransformation aging phenomenon is observed in the fissium alloy. The consequences of this are illustrated in Figure 13 by the hardness changes obtained on an alloy bar which was end quenched. The hardness changes are representative of those obtained at cooling rates varying from water quenching to air cooling. A distinct hardness plateau of about $207 \mathrm{VHN}$ separates two hardness increases. 


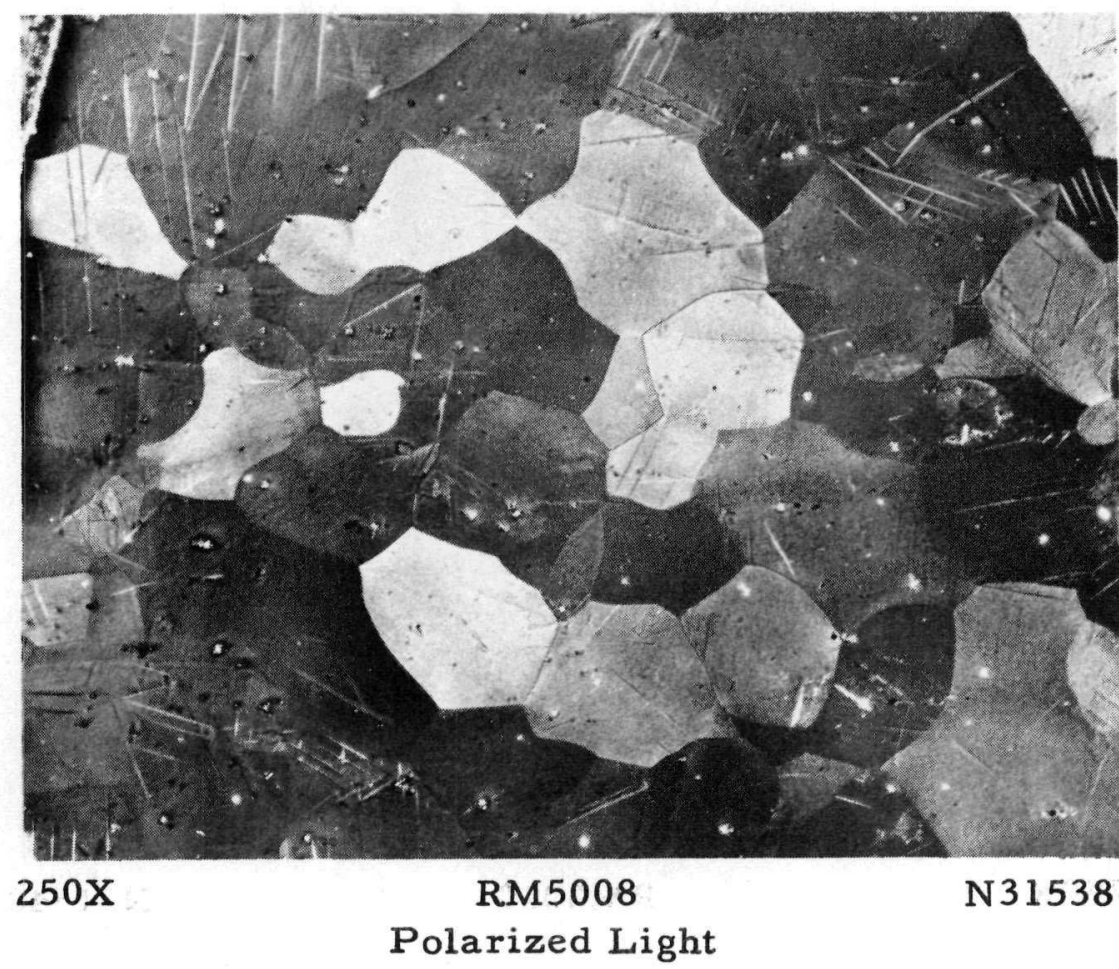

FIGURE 7. FISSIUM ALLOY HEAT TREATED FOR I HR AT 825 C AND WATER QUENCHED

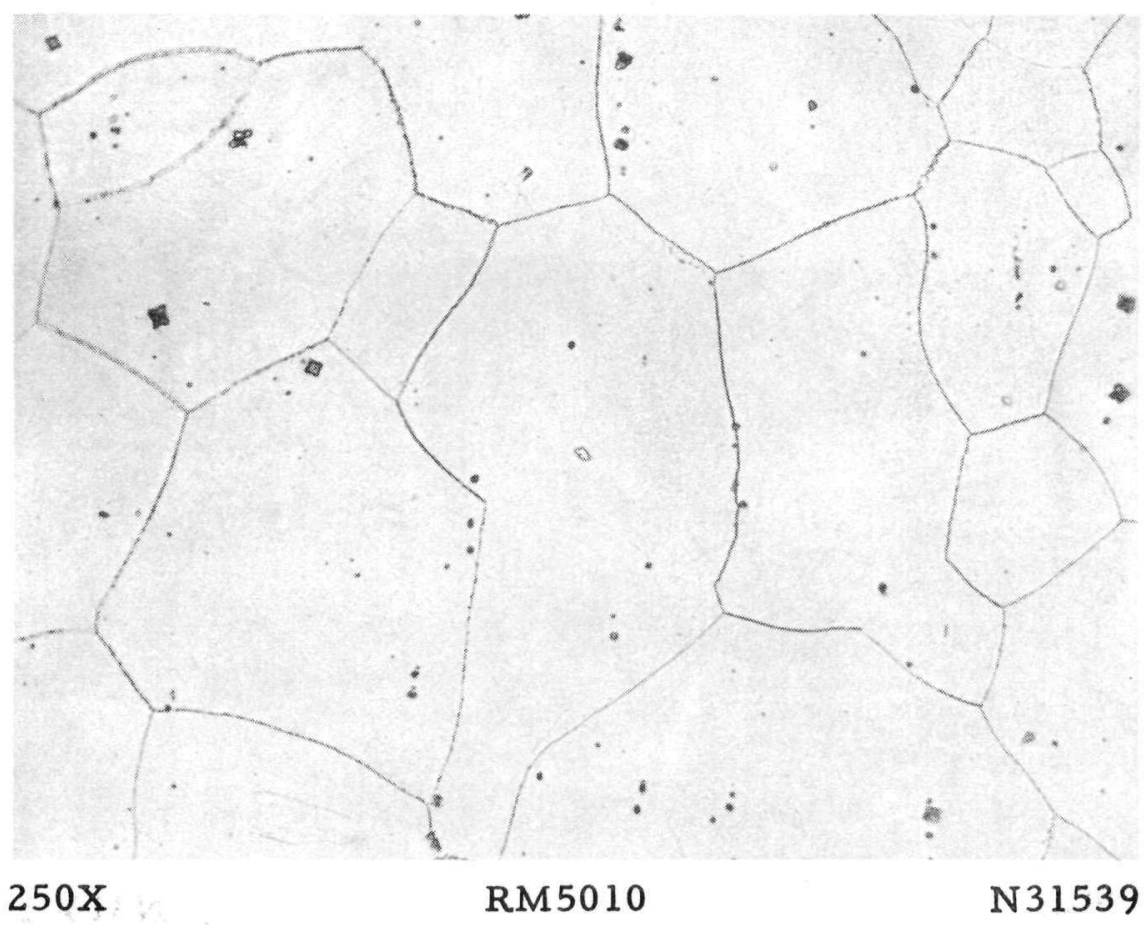

FIGURE 8. FISSIUM ALLOY HEAT TREATED FOR 1 HR AT $800 \mathrm{C}$ AND ISOTHERMALLY TRANSFORMED FOR 100 SEC AT $500 \mathrm{C}$ AND WATER QUENCHED 


\section{6}

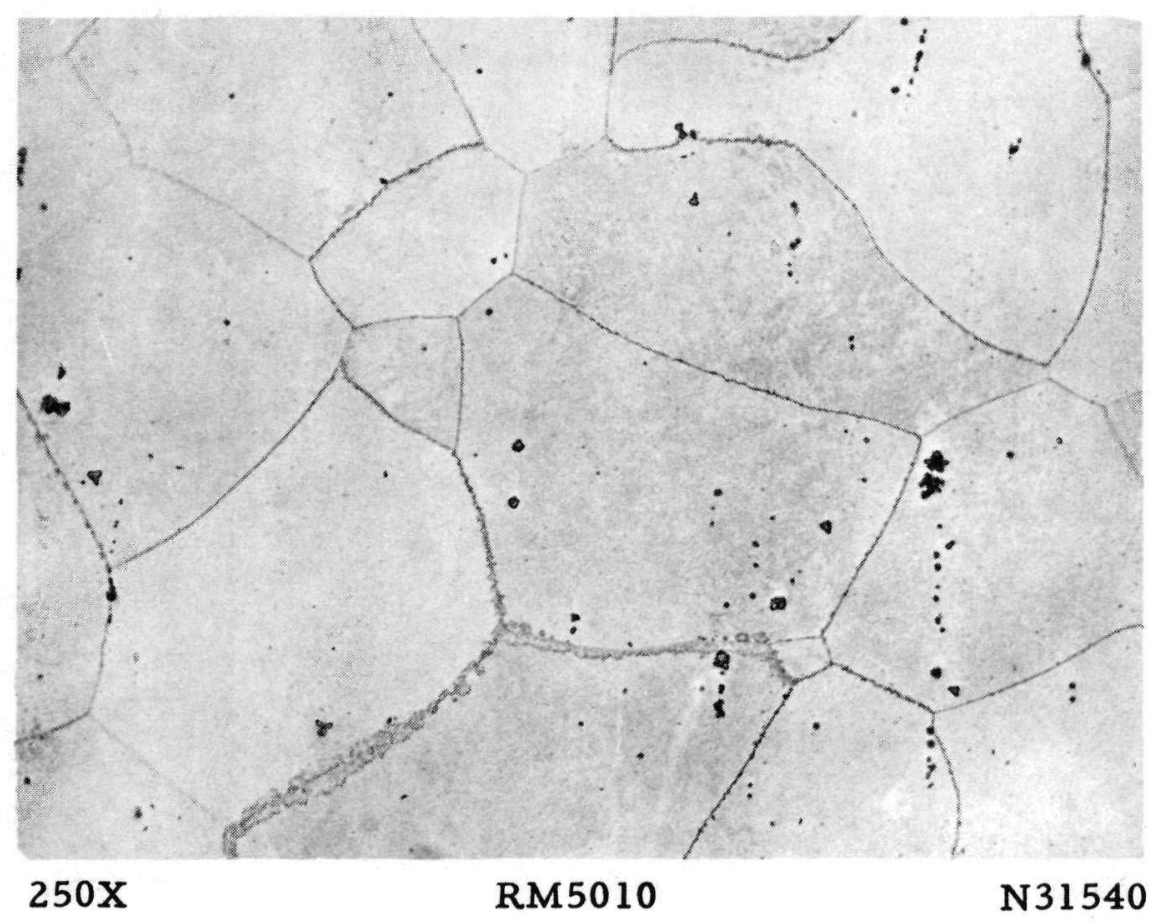

FIGURE 9. FISSIUM ALLOY HEAT TREATED FOR 1 HR AT 825 C AND ISOTHERMALLY TRANSFORMED FOR 400 SEC AT $500 \mathrm{C}$ AND WATER QUENCHED

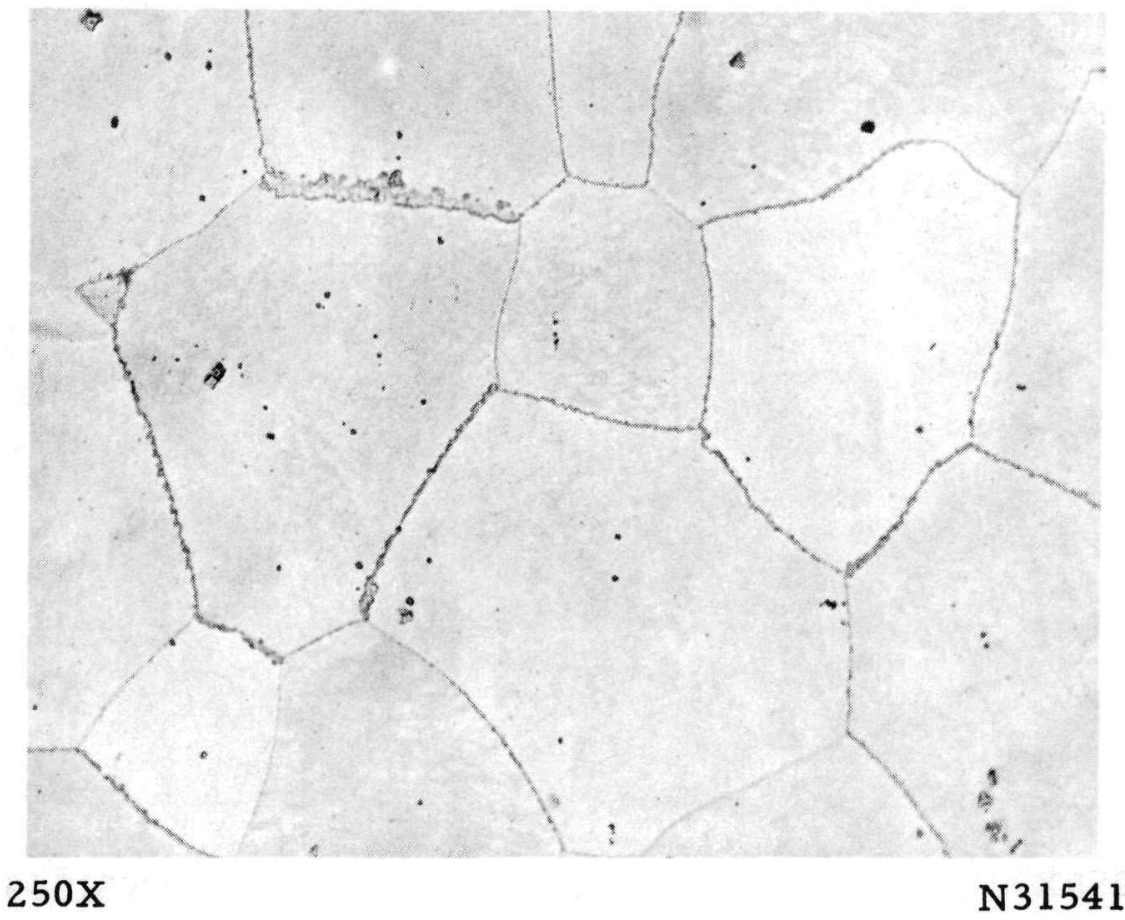

FIGURE 10. FISSIUM ALLOY HEAT TREATED FOR 1 HR AT $825 \mathrm{C}$ AND ISOTHERMALLY TRANSFORMED FOR 2000 SEC AT 500 C AND WATER QUENCHED 


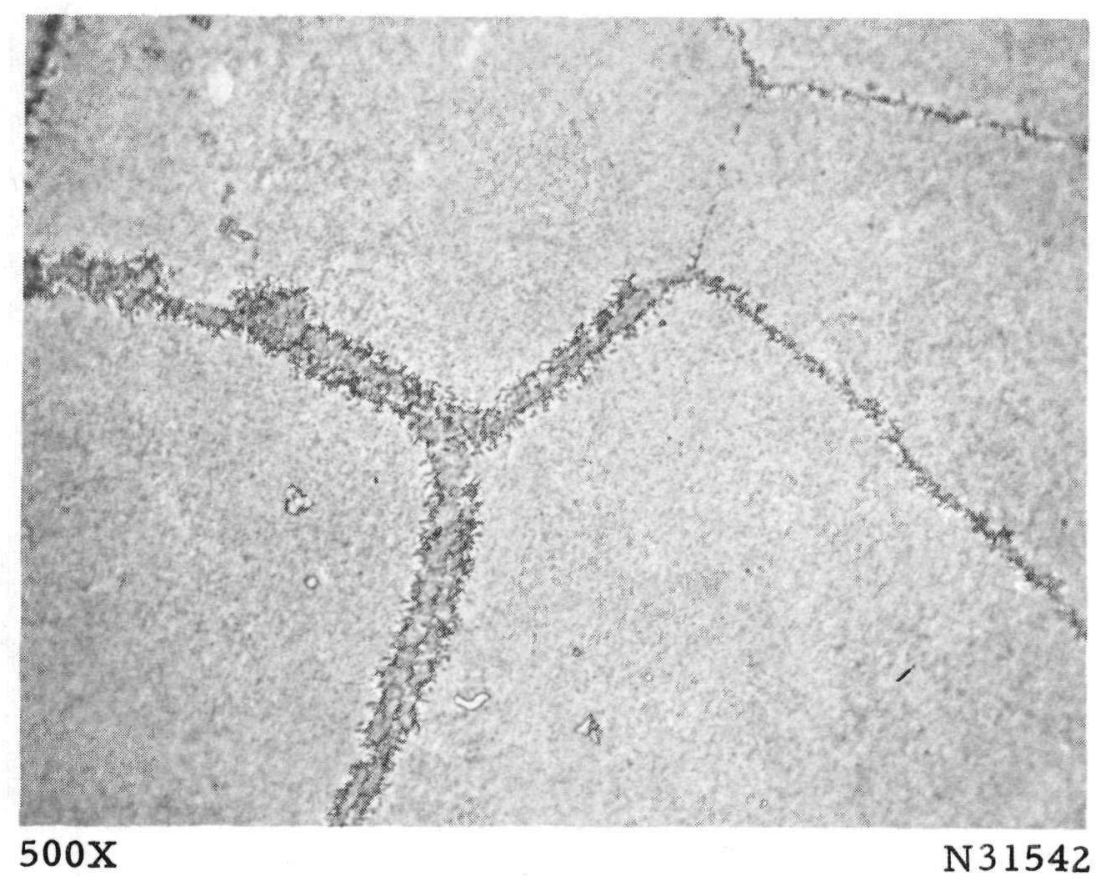

FIGURE 11. FISSIUM ALLOY HEAT TREATED FOR 1 HR AT $825 \mathrm{C}$ AND ISOTHERMALLY TRANSFORMED FOR 26 HR AT $500 \mathrm{C}$ AND WATER QUENCHED 


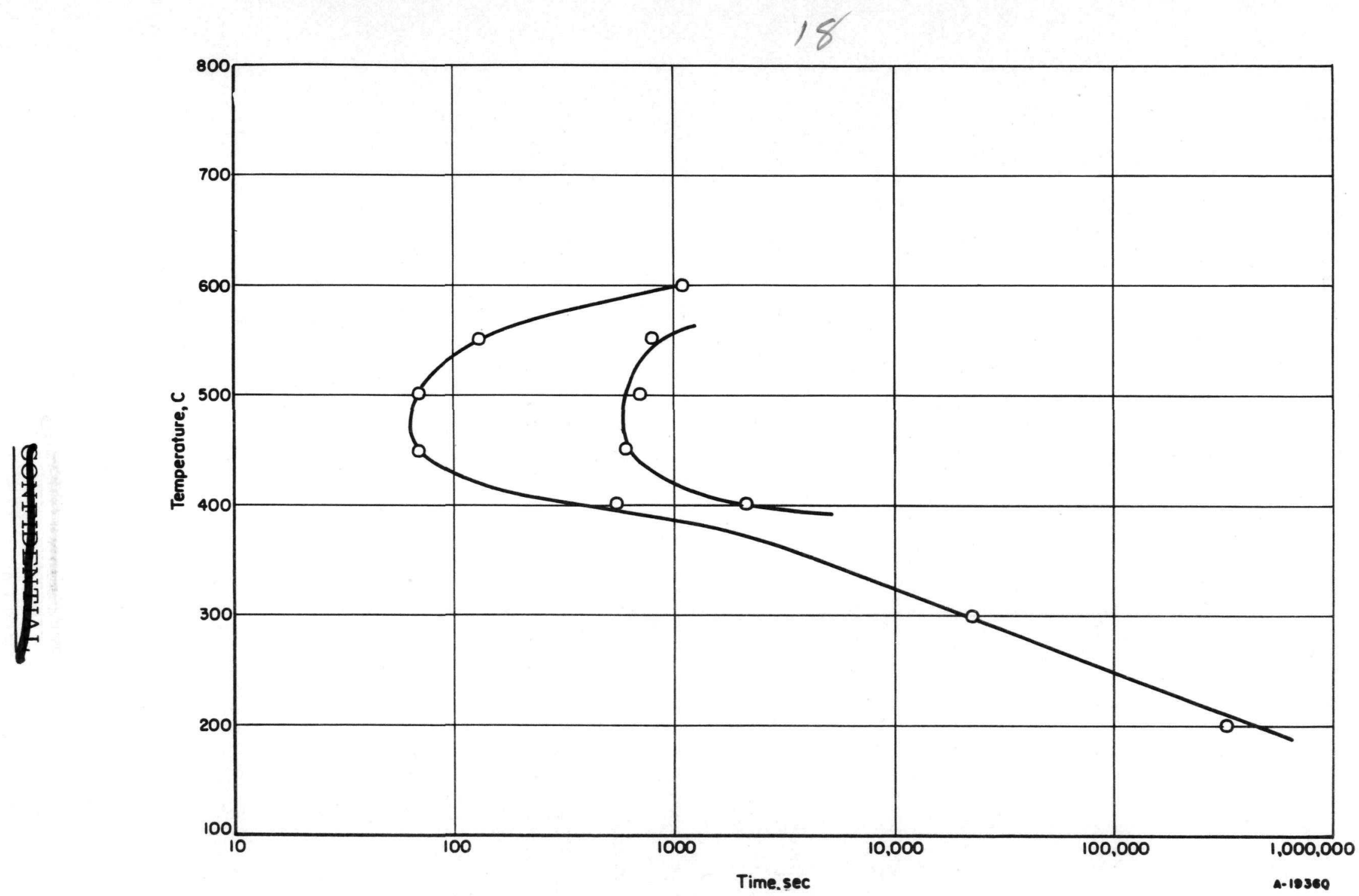

FIGURE 12. TIME-TEMPERATURE RELATIONSHIPS FOR THE BEGINNING AND END OF HARDNESS INCREASE IN AN ISOTHERMALLY TRANSFORMED FISSIUM ALLOY 


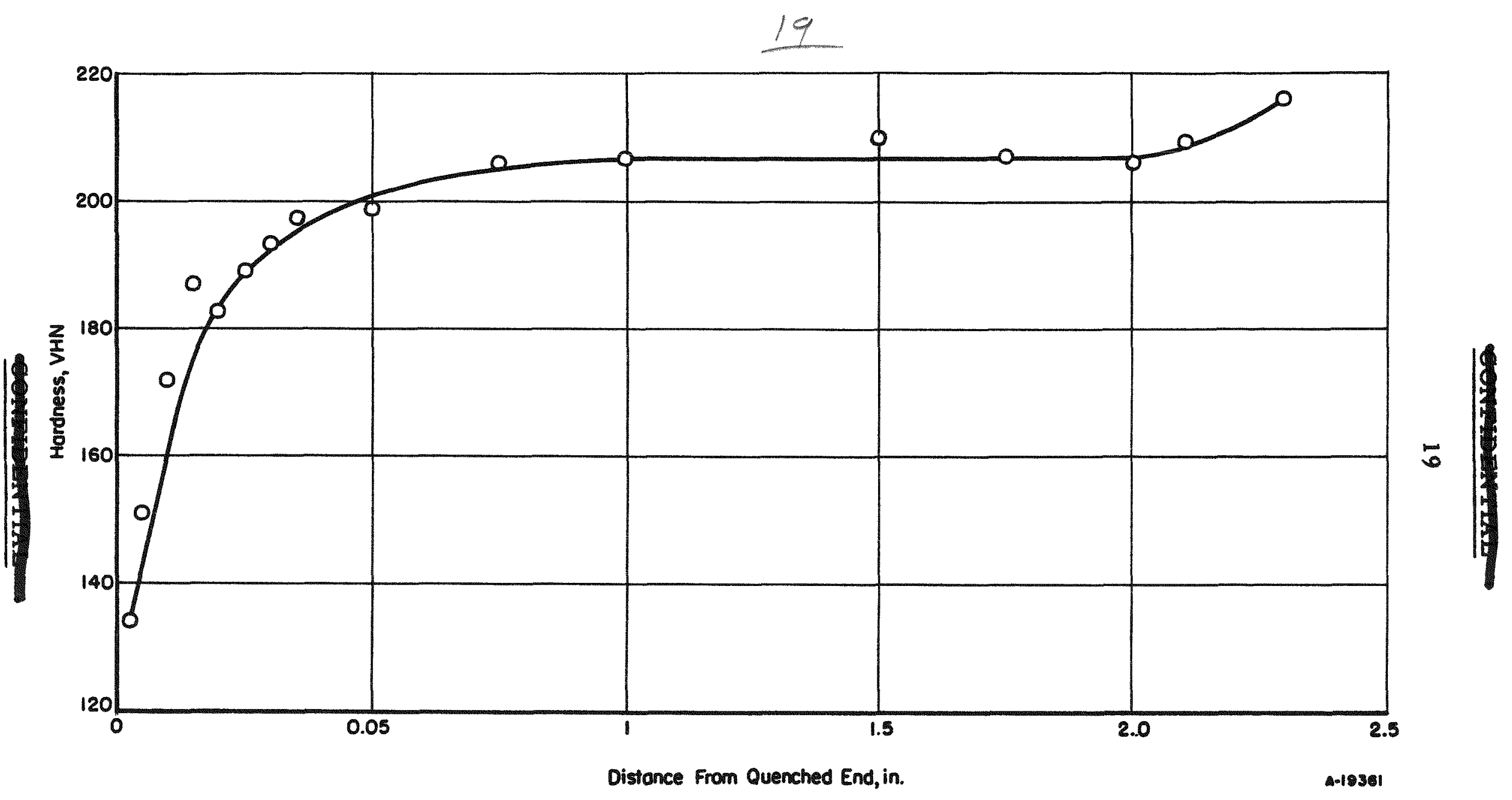

FIGURE 13. HARDNESS CHANGES IN A FISSIUM-ALLOY BAR END QUENCHED AFTER I HR AT $825 \mathrm{C}$ 
Examination of the hardness curves obtained from isothermally transformed specimens shows that this same hardness change occurs at 200 , 300 , and $400 \mathrm{C}$. X-ray diffraction examination of a specimen transformed for $3 \mathrm{hr}$ at $300 \mathrm{C}$ revealed a retained-gamma structure with a trace of alpha uranium, indicating that the hardness increase represents an aging of the gamma phase.

It, therefore, appears that, at low temperatures, precipitation aging of the gamma phase precedes the transformation of gamma to alpha uranium. However, whether the absence of this aging phenomena at $450 \mathrm{C}$ and above indicates that this pretransformation precipitation does not proceed at higher temperatures, or that the aging effects are annealed out as a result of the higher temperatures, is uncertain.

The hardness changes produced by various furnace-cooling treatments are listed below:

Heat Treatment

$1 \mathrm{hr}$ at $800 \mathrm{C}$ and furnace cool

$1 \mathrm{hr}$ at $800 \mathrm{C}$ and furnace cool to $700 \mathrm{C}$, hold $24 \mathrm{hr}$ and furnace cool

$1 \mathrm{hr}$ at $800 \mathrm{C}$ and furnace cool to $625 \mathrm{C}$, hold for $24 \mathrm{hr}$ and furnace cool

Comparison of the hardness values for the various treatments indicates that any precipitation occurring on cooling from $800 \mathrm{C}$ to $700 \mathrm{C}$ has no effect on the hardening mechanism in the alloy and that the most effective means of reducing the hardness in the alloy is an overaging treatment of the alpha phase at a temperature of at least $625 \mathrm{C}$.

\section{PHYSICAL PROPERTIES}

\section{Melting Point}

The melting-point determinations on the alloy were made utilizing small slivers cut from the rolled material. A Chromel-Alumel thermocouple was welded between two of the slivers and the resulting sandwich was clad in a platinum envelope. The clad envelope was then inserted into a hot furnace while a time-temperature record was obtained on a high-speed recorder. The data are given on the following page. 


\begin{tabular}{cc} 
Beginning of Melting, $F$ & End of Melting, $F$ \\
\hline 1830 & 1973 \\
1832 & 1980 \\
1845 & 1978 \\
Average $1836(1002 \mathrm{C})$ & $1977(1081 \mathrm{C})$
\end{tabular}

$\underline{\text { Fluidity }}$

Fluidity tests were conducted in a vacuum induction-type furnace utilizing a foundry-type spiral graphite mold. The superheats used and results of these tests are listed below:

$\begin{array}{cccc}\text { Pouring Temperature, } F & & \text { Superheat, } F & \text { Amount of Flow, in. } \\ {)} } & 125(69 \mathrm{C}) & 3 / 16 \\ 2277(1245 \mathrm{C}) & 300(167 \mathrm{C}) & 1 / 2 \\ 2402(1317 \mathrm{C}) & 425(236 \mathrm{C}) & 1\end{array}$

Thermal Conductivity

Thermal-conductivity measurements were made by the steady-heatflow method. During the test, the specimen was protected by a vacuum of approximately $1 \times 10^{-5} \mathrm{~mm}$ of mercury. Five thermocouples, equally spaced along the length of the specimen, were used to measure the temperature drops along the specimen. Four thermal-equilibrium tests were run, yielding a total of 20 values. These values were plotted on a graph of thermal conductivity versus temperature. The data shown in Table 2 are taken from a mean curve drawn through the experimental points. The absolute accuracy of the reported values is estimated to be \pm 5 per cent.

The thermal-conductivity values of the fissium alloy as well as similar values obtained on pure uranium and on a uranium-10 w/o molybdenum alloy are shown in Figure 14. From the graph it can be seen that the fissium alloy possesses greater thermal conductivity than does the uranium- $10 \mathrm{w} / \mathrm{o}$ molybdenum alloy at temperatures exceeding $100 \mathrm{C}$. As the temperature is increased, this difference in thermal conductivity becomes more pronounced and at $800 \mathrm{C}$ it increased approximately tenfold over its value at $100 \mathrm{C}$.

Pure uranium possesses greater thermal conductivity than either of the alloys. The greatest differences occur at the lower temperatures. However, as the temperature increases the differences in the thermal conductivities decrease and if the values for the uranium are extrapolated, 
22

TABLE 2. THERMAL CONDUCTIVITY OF THE FISSIUM ALLOY

\begin{tabular}{cc}
\hline Temperature, $F$ & $\begin{array}{c}\text { Thermal Conductivity, } \\
\mathrm{w} /(\mathrm{cm} 2)(\mathrm{cm})(\mathrm{C})\end{array}$ \\
\hline 20 & 0.110 \\
100 & 0.143 \\
200 & 0.183 \\
300 & 0.221 \\
400 & 0.260 \\
500 & 0.298 \\
600 & 0.334 \\
700 & 0.370 \\
800 & 0.407 \\
900 & 0.441 \\
\hline
\end{tabular}




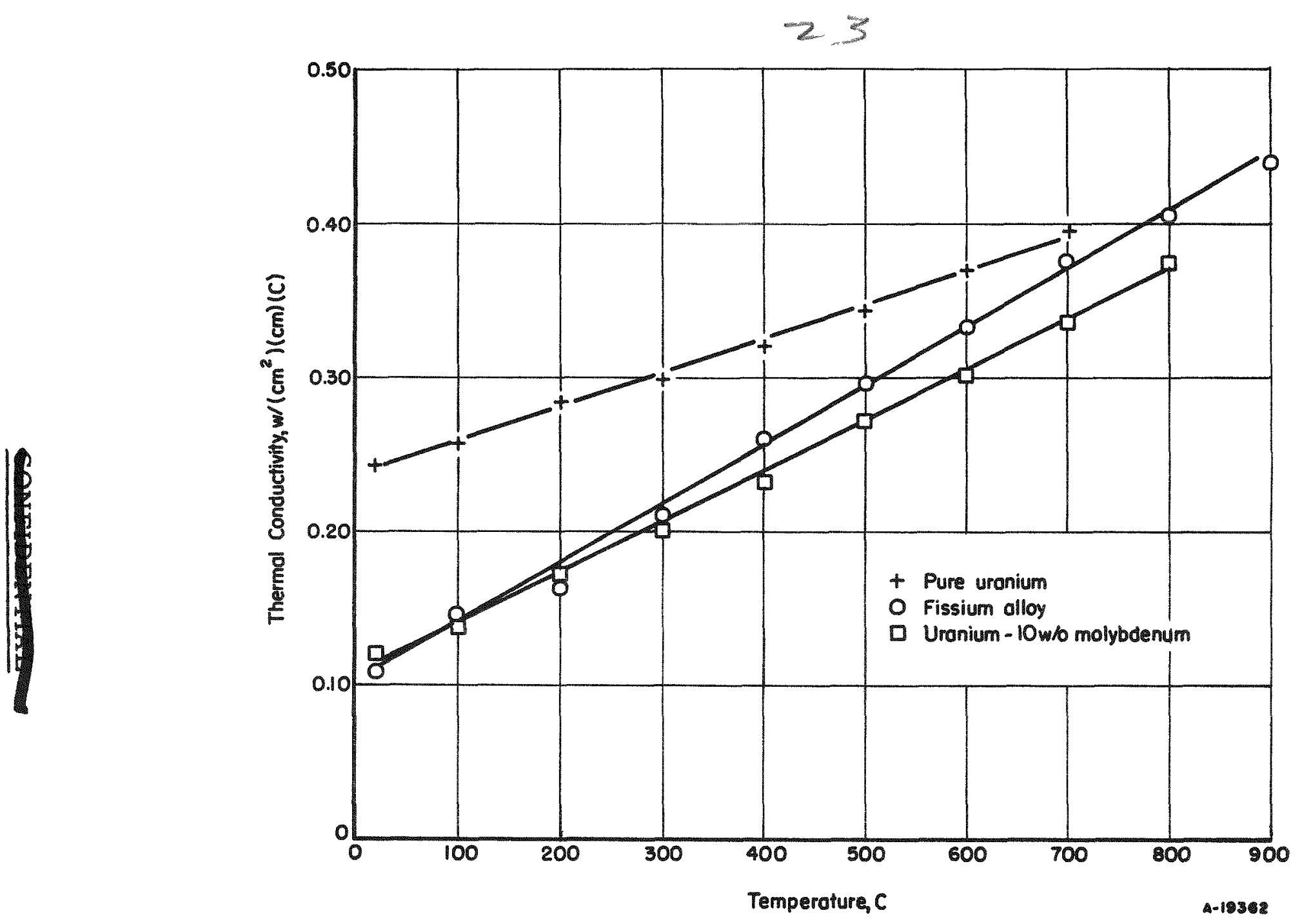

FIGURE 14. COMPARISON OF THE THERMAL CONDUCTIVITY OF THE FISSIUM ALLOY WITH UNALLOYED URANIUM AND URANIUM- 10 w/O MOL YBDENUM 
it can be seen that the thermal conductivity values for the fissium and the uranium will be equal at approximately $840 \mathrm{C}$. However, it would be necessary to extrapolate the uranium and the uranium-10 w/o molybdenum curves to temperatures in excess of $1200 \mathrm{C}$ before they would intersect. From these data it can be said that at temperatures within the normal operating range of a reactor the thermal conductivity of the fissium-type alloy compares more favorably with unalloyed uranium than it does to the uranium-10 w/o molybdenum alloy.

\section{Linear Thermal Expansion}

Linear-thermal-expansion measurements were made in a recording quartz-tube dilatometer. The specimen was protected by a vacuum of approximately $5 \times 10^{-5} \mathrm{~mm}$ of mercury during the test. Table 3 shows the mean linear coefficients of thermal expansion over the temperature ranges shown. Figure 15 shows the curve for linear thermal expansion versus temperature for the alloy. Figure 16 shows the linear thermal expansion of a uranium-5 w/o molybdenum alloy, which is representative of uraniummolybdenum alloys containing up to $10 \mathrm{w} / 0$ molybdenum. Upon inspection of these graphs, it can be seen that the fissium alloy in the gamma-quenched condition exhibits a much greater difference in linear expansion between the heating and cooling cycles than do the uranium-molybdenum alloys in this composition range. There is also evidence of contraction taking place in the fissium alloy during the heating cycle at approximately $475 \mathrm{C}$. This is no doubt the result of transformation of the gamma during heating.

TABLE 3. MEAN COEFFICIENT OF LINEAR THERMAL EXPANSION OF THE FISSIUM ALLOY OVER THE TEMPERATURE RANGES SHOWN

\begin{tabular}{ccc}
\hline \multirow{2}{*}{$\begin{array}{c}\text { Temperature Range, } \\
\text { C }\end{array}$} & \multicolumn{2}{c}{$\begin{array}{c}\text { Cean Coefficient of Linear Thermal } \\
\text { Expansion, per C x } 10^{6}\end{array}$} \\
\cline { 2 - 3 } $20-100$ & Heating & Cooling \\
$20-200$ & 11.0 & 13.7 \\
$20-300$ & 12.5 & 14.4 \\
$20-400$ & 13.6 & 15.1 \\
$20-500$ & 14.0 & 15.7 \\
$20-650$ & -- & -- \\
$20-700$ & 16.6 & -- \\
$20-800$ & 16.6 & 23.3 \\
\hline
\end{tabular}




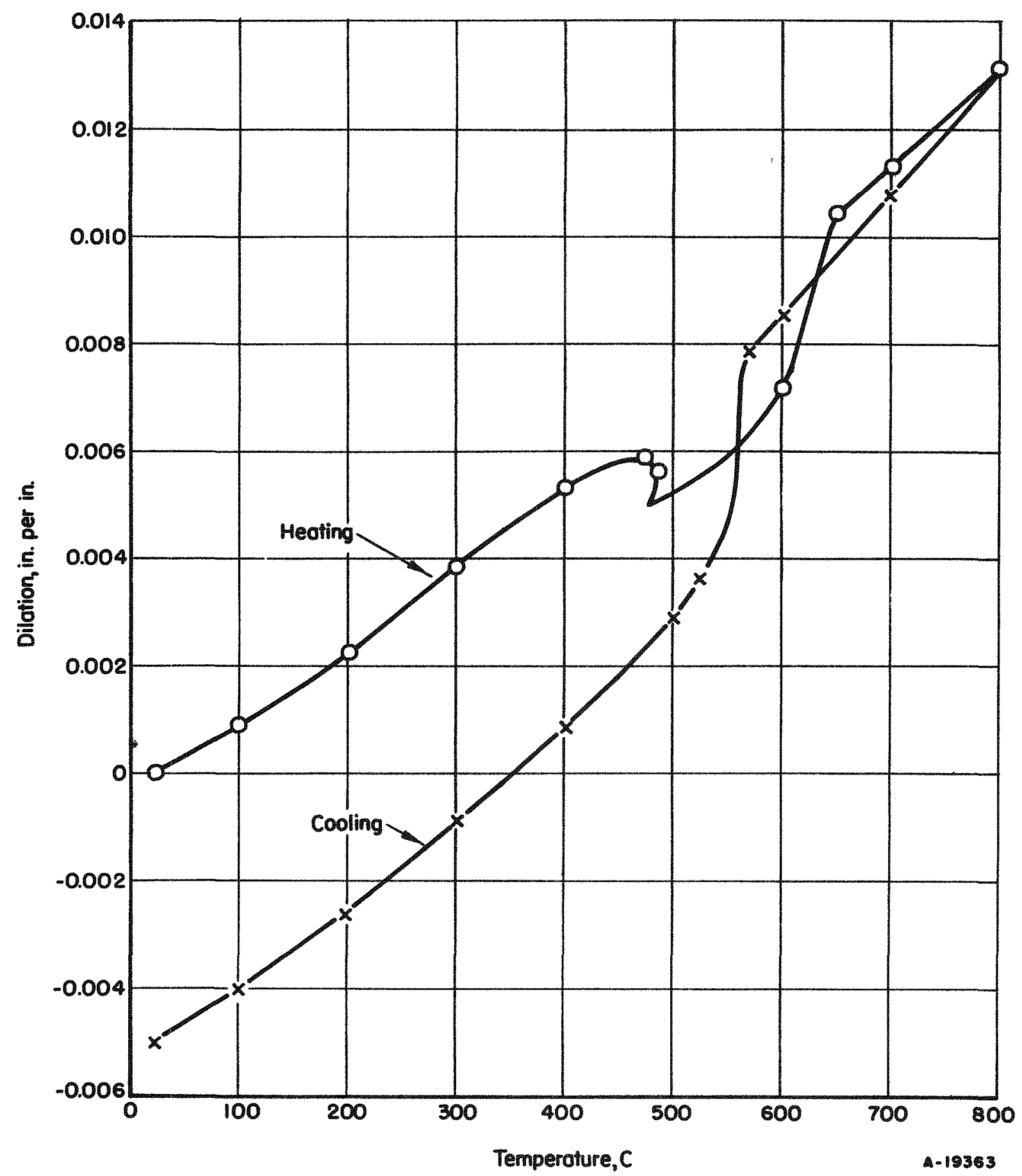

FIGURE 15. LINEAR THERMAL EXPANSION VERSUS TEMPERATURE OF THE FISSIUM ALLOY WATER QUENCHED FROM $675 \mathrm{C}$ 


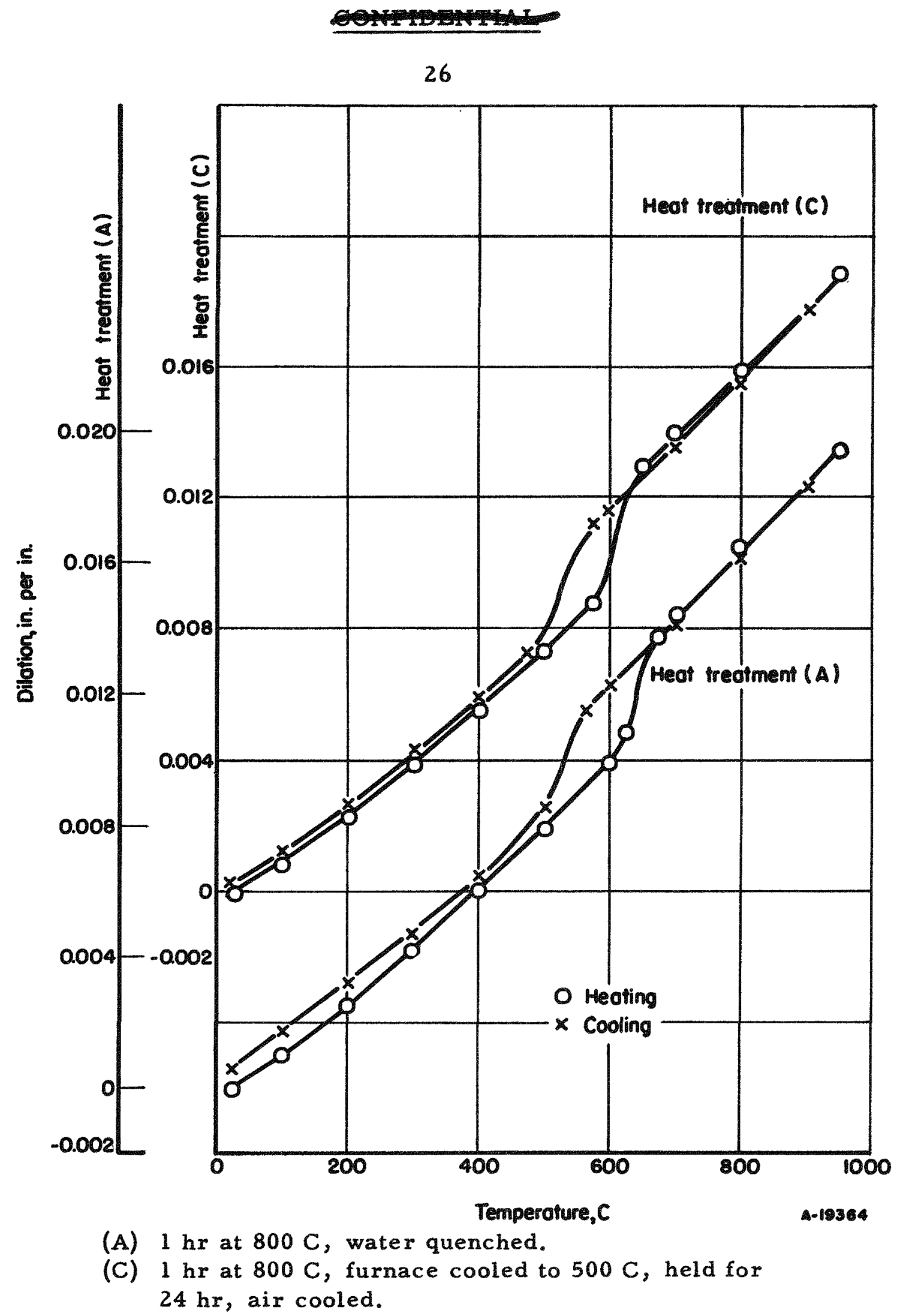

FIGURE 16. LINEAR THERMAL EXPANSION VERSUS TEMPERATURE FOR THE URANIUM-5 w/O MOLYBDENUM ALLOY 
Density

Table 4 shows the density values of the alloy at the temperatures indicated. The room-temperature value was obtained from the measured volume and weight of the specimen. The density values at elevated temperatures were calculated from the heating thermal-expansion data. It was assumed that the alloy was isotropic and that the volume-thermal-expansion coefficient was equal to three times the linear-thermal-expansion coefficient.

TABLE 4. DENSITY OF THE FISSIUM ALLOY

\begin{tabular}{cc}
\hline \hline $\begin{array}{c}\text { Temperature, } \\
\text { C }\end{array}$ & $\begin{array}{c}\text { Density, } \\
\text { g per } \mathrm{cm}^{3}\end{array}$ \\
\hline 20 & 17.95 \\
650 & 17.4 \\
700 & 17.4 \\
800 & 17.3 \\
\hline
\end{tabular}

Thermal Stability

Thermal-stability tests were conducted on specimens of the alloy approximately $1 / 2$ in. in diameter by 1 in. long. Four specimens which were hot rolled at $675 \mathrm{C}$ were sealed in evacuated Vycor tubes and cycled 250 times in the temperature range from 150 to $725 \mathrm{C}$. Two of the se specimens exhibited very little visual deformation as shown in Figure 17, but they grew approximately 3.1 per cent in length. The other two specimens were deformed to a greater extent and grew more than 6 per cent in length with a corresponding decrease in diameter. These two specimens are shown in Figure 18. The growth exhibited by the specimens in both cases was much greater than that exhibited by uranium-molybdenum alloys, containing 3.5 to $10 \mathrm{w} / \mathrm{o}$ molybdenum, which were cycled in the same manner. The variations in deformation and growth of these samples may be the result of minor differences in fabrication, since the rolling temperature was just above the temperature where alpha occurs.

\section{Hot Hardness}

Hot-hardness values are often an indication of the relative hightemperature strength of an alloy. The ease with which values may be 


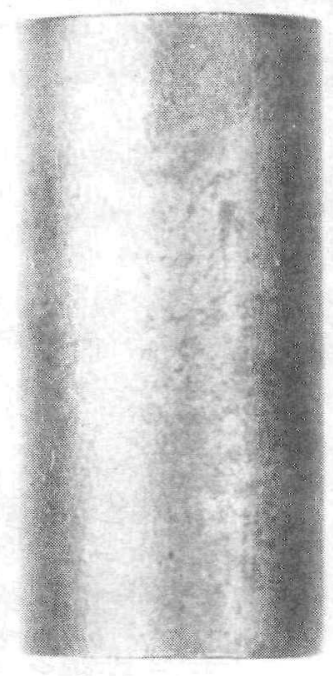

2. $5 \mathrm{X}$

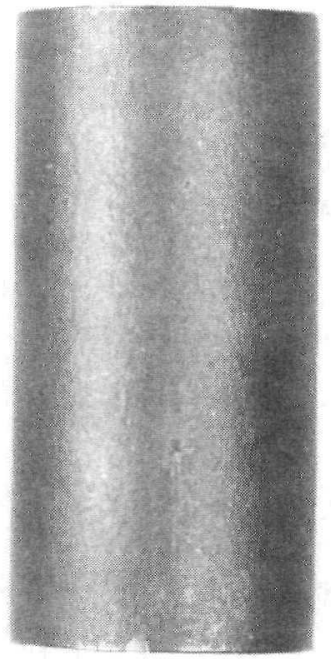

N31543

FIGURE 17. FISSIUM-ALLOY SPECIMENS NOT EXHIBITING VISUAL DEFORMATION AFTER THERMAL-STABILITY TESTS

These specimens elongated 3.1 per cent when cycled 250 times between 150 and $725 \mathrm{C}$.

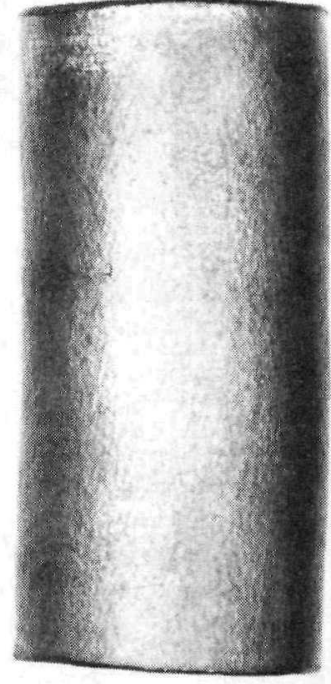

1

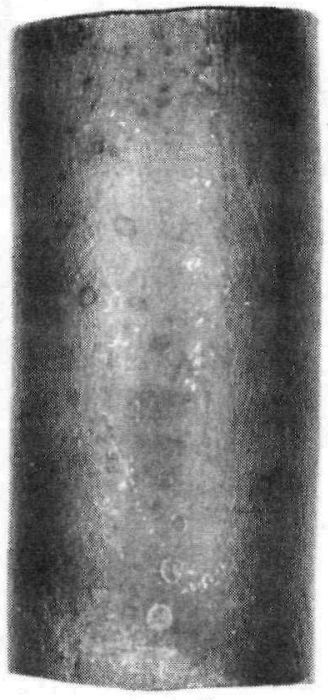

wam

2. $5 \mathrm{X}$

N31544

FIGURE 18. FISSIUM-ALLOY SPECIMENS SHOWING VISUAL DEFORMATION AFTER THERMAL-STABILITY TESTS

These specimens elongated over 6 per cent when cycled 250 times between 150 and $725 \mathrm{C}$. 
TABLE 5. HOT HARDNESS OF URANIUM, THE FISSIUM ALLOY, AND OF TWO URANIUM-MOL YBDENUM ALLOYS

\begin{tabular}{|c|c|c|c|c|}
\hline \multirow{2}{*}{$\begin{array}{c}\text { Temperature, } \\
\mathrm{C}\end{array}$} & \multicolumn{4}{|c|}{$\begin{array}{c}\text { Hot Hardness, DPH } \\
\text { kg per } \mathrm{mm}^{2}\end{array}$} \\
\hline & Uranium & Fissium & $\mathrm{U}-5 \mathrm{w} / \mathrm{o} \mathrm{Mo}$ & $\mathrm{U}-9 \mathrm{w} / \mathrm{o} \mathrm{Mo}$ \\
\hline R. T. & 208 & 125 & 119 & 276 \\
\hline 100 & 162 & -- & -- & -- \\
\hline 200 & 119 & -- & - & -- \\
\hline 300 & 84 & 264 & -- & -- \\
\hline 400 & 52 & 394 & 152 & 136 \\
\hline 450 & -- & 324 & -- & -- \\
\hline 500 & 28 & 179 & 104 & 120 \\
\hline 550 & - & 89 & 65.6 & 111 \\
\hline 600 & 16 & 22.5 & 26 & 89 \\
\hline 650 & 11,30 & 10.6 & 19 & 69 \\
\hline 700 & 33 & 7.1 & 13.2 & 51 \\
\hline 750 & $26,1.5$ & 4.8 & 9.3 & 38 \\
\hline 800 & -- & 3.7 & 7.5 & 30 \\
\hline
\end{tabular}




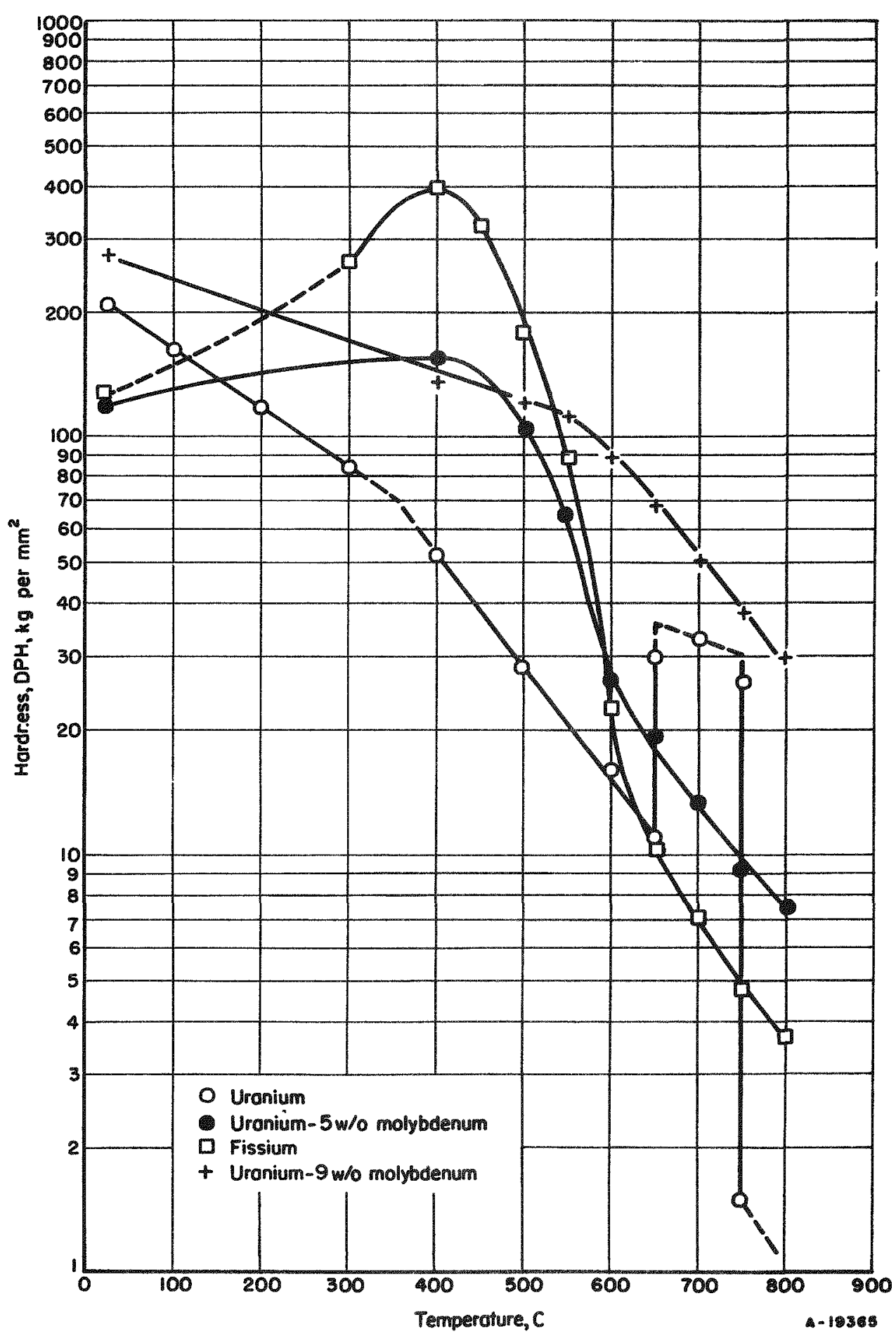

FIGURE 19. COMPARISON OF HOT-HARDNESS VALUES FOR URANIUMMOLYBDENUM ALLOYS AND THE FISSIUM ALLOY 
TABLE 6. TENSILE PROPERTIES OF THE FISSIUM ALLOY, URANIUM-5 w/O MOLYBDENUM ALLOY, AND URANIUM AT SEVERAL TEMPERATURES

\begin{tabular}{|c|c|c|c|c|c|c|}
\hline $\begin{array}{c}\text { Test } \\
\text { Temperature, } \\
\mathrm{C} \\
\end{array}$ & $\begin{array}{c}\text { Material } \\
\text { Composition }\end{array}$ & $\begin{array}{c}\text { Young's } \\
\text { Modulus, } \\
\text { psi }\end{array}$ & $\begin{array}{c}\text { Per Cent } \\
\text { Yield } \\
\text { Strength, } \\
\text { psi }\end{array}$ & $\begin{array}{c}\text { Ultimate } \\
\text { Strength, } \\
\text { psi }\end{array}$ & $\begin{array}{l}\text { Elongation } \\
\text { in } 2 \text { In., } \\
\text { per cent }\end{array}$ & $\begin{array}{l}\text { Reduction } \\
\text { in Area, } \\
\text { per cent }\end{array}$ \\
\hline 290 & Fissium & $9.9 \times 10^{6}$ & (a) & -- & -- & -- \\
\hline 300 & Pure U & -- & 17,500 & 35,200 & 49 & -- \\
\hline 500 & Pure U & -- & 5,450 & 10,450 & 57 & -- \\
\hline 540 & Fissium & $8.6 \times 10^{6}$ & 12,640 & 32,630 & 13.3 & 25 \\
\hline 540 & Fissium & $9.6 \times 10^{6}$ & 15,000 & 43,300 & 8.6 & 17 \\
\hline 540 & $\mathrm{U}-5 \mathrm{w} / \mathrm{\circ} \mathrm{Mo}$ & -- & 14,000 & 31,850 & -- & -- \\
\hline 690 & Fissium & -- & (b) & 2,120 & $100(c)$ & -- \\
\hline 690 & Fissium & -- & (b) & 2,330 & $100(c)$ & -- \\
\hline 690 & $\mathrm{U}-5 \mathrm{w} / \mathrm{O} \mathrm{MO}$ & -- & 2,810 & 4,070 & $100(c)$ & -- \\
\hline
\end{tabular}

(a) Broke in grip before reaching 0.2 per cent offset. Stress in reduced section at maximum load was 77,500 psi。

(b) Temperature too high for satisfactory yield-strength determination.

(c) Specimens elongated to limit of tank but did not fracture.

Note: Tensile properties of pure uranium were taken from AECD-3647. Those of uranium-molybdenum alloys were taken from unpublished information. 


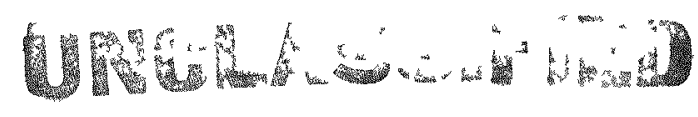
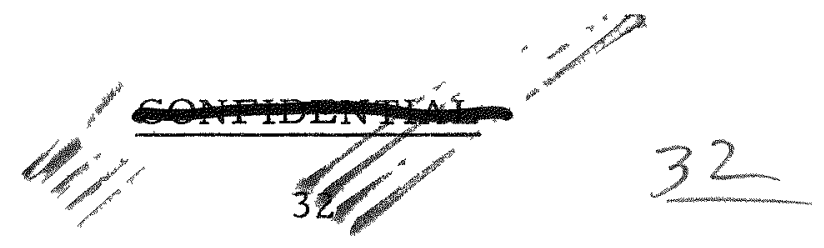

obtained over a wide temperature range makes this method practical in some cases for determining temperature ranges in which transformation of the alloy occurs. The values listed in Table 5 show a very decided decrease in hardness in the temperature range between 450 and $500 \mathrm{C}$. This is probably due to overaging or recrystallization of the alloy.

The hardness data obtained on the fabricated and water-quenched alloy and similar data obtained on pure uranium and on two uranium-molybdenum alloys, listed in Table 5, are plotted in Figure 19 on a hardness versus temperature graph. The curves exhibited by the fissium alloy and the $5 \mathrm{w} / \mathrm{o}$ molybdenum alloy are similar. The increase in hardness occurring from 300 to $450 \mathrm{C}$ may be compared to the blue-brittleness phenomena in steels. At temperatures above $600 \mathrm{C}$, the fissium alloy softens faster than does either the 5 or $9 \mathrm{w} / \mathrm{o}$ molybdenum alloys. The effects of age hardening are not exhibited by the $9 \mathrm{w} / \mathrm{o}$ alloy because the time interval during which the specimen is at the elevated temperatures is not sufficient to allow the more sluggish reaction to occur. Although it would appear from the hardness readings that the fissium alloy could be fabricated at temperatures as low as $600 \mathrm{C}$, this did not prove to be true in actual practice.

\section{Tensile Properties}

The tensile properties of the alloy were investigated at 290,540, and $690 \mathrm{C}$ in vacuum with a strain rate above yield of $0.02 \mathrm{in}$. per min crosshead speed. Flat-plate-type specimens in the as-rolled condition were used for these tests. Comparative data were also obtained on pure uranium and on a uranium $-5 \mathrm{w} / 0$ molybdenum alloy. The results of these tests are shown in Table 6. No attempt can be made to compare the tensile properties of these alloys due to the paucity of available information.

\section{CONCLUSIONS}

It is significant that the low fluidity of the alloy and its tendency to be very porous when cast under a partial pressure of an inert gas will offer some problems to those intending to utilize the alloy for fuel elements. However, once a sound casting is obtained, it can be hot fabricated readily to almost any desirable shape and size. The tensile properties of the alloy compare favorably with the uranium-5 w/o molybdenum alloy at 540 and $690 \mathrm{C}$, but unpublished data indicate that the $9 \mathrm{w} / \mathrm{o}$ molybdenum alloy is superior in this temperature range. Another factor that may be detrimental to the use of such an alloy in reactors is the extreme hardening and embrittling reaction that occurs during heat treatment.

HAS:RFD:AAB:NED/mmk 